Federal Reserve Bank of Minneapolis

Research Department Staff Report 374

May 2006

\title{
Inside and Outside Money
}

\author{
Ricardo Lagos \\ Federal Reserve Bank of Minneapolis \\ and New York University
}

\begin{abstract}
A distinction is drawn between outside money-money that is either of a fiat nature or backed by some asset that is not in zero net supply within the private sector-and inside money, which is an asset backed by any form of private credit that circulates as a medium of exchange.
\end{abstract}

*This paper has been prepared for the New Palgrave Dictionary of Economics, 2nd edition. I thank Narayana Kocherlakota and Warren Weber for comments. I also thank the C.V. Starr Center for Applied Economics at New York University for financial support. The views expressed herein are those of the author and not necessarily those of the Federal Reserve Bank of Minneapolis or the Federal Reserve System. 


\section{Inside and Outside Money}

\section{Definitions}

Money is an asset that serves as a medium of exchange.

Outside money is money that is either of a fiat nature (unbacked) or backed by some asset that is not in zero net supply within the private sector of the economy. Thus, outside money is a net asset for the private sector. The qualifier outside is short for (coming from) outside the private sector. Inside money is an asset representing, or backed by, any form of private credit that circulates as a medium of exchange. Since it is one private agent's liability and at the same time some other agent's asset, inside money is in zero net supply within the private sector. The qualifier inside is short for (backed by debt from) inside the private sector.

\section{Background}

In 1960, John G. Gurley and Edward S. Shaw published Money in a Theory of Finance. In this book, they attempted to develop a theory of finance that encompasses the theory of money and a theory of financial institutions that includes banking theory.

Consider a simple economy similar to the one considered by Gurley and Shaw. The economy has fiat money — an intrinsically useless asset with no backing whatsoever-that is generally accepted as a means of payment. A monetary authority or "government" has the monopoly to issue this asset. The economy is closed and consists of three sectors: households, firms, and government. Firms issue debt in the form of homogeneous, perfectly safe nominal bonds. (For example, think of these bonds as being promises to pay $\$ 1$ at some future date.) 
Table 1

\begin{tabular}{|c|c|c|c|}
\hline \multicolumn{4}{|c|}{ Households } \\
\hline \multicolumn{2}{|c|}{ Assets } & \multicolumn{2}{|c|}{ Liabilities } \\
\hline Money & 50 & & \\
\hline Bonds & 25 & & \\
\hline \multirow[t]{2}{*}{ Equity } & 275 & & \\
\hline & & NW & 350 \\
\hline
\end{tabular}

\begin{tabular}{ll|lc}
\hline \hline \multicolumn{3}{c}{ Firms } \\
\hline \multicolumn{2}{c|}{ Assets } & \multicolumn{2}{c}{ Liabilities } \\
\hline Money 100 & Bonds & 25 \\
Capital 200 & Equity & 275 \\
& & & \\
\hline & NW & 0 \\
\hline \hline
\end{tabular}

\begin{tabular}{l|ll}
\hline \hline \multicolumn{2}{c}{ Government } \\
\hline Assets & \multicolumn{2}{|c}{ Liabilities } \\
\hline & Money & 150 \\
& & \\
& & \\
\hline & NW & -150 \\
\hline
\end{tabular}

Table 1 shows hypothetical sectoral balance sheets for this economy. In this example, households hold only financial wealth (i.e., no real wealth such as houses), in particular money, equity on the firms, and the bonds issued by the firms. Here households have no liabilities, so their net worth (NW) is just the sum of the value of their assets. The assets owned by firms consist of cash and physical capital. A part of these assets has been financed with debt (bonds) and another part by issuing equity. The former represent the firms' liabilities toward the bond holders, and the latter represent the firms' liabilities toward shareholders. The firm's net worth (net of equity) is zero. The government has no real assets, but at some point in the past, it issued financial assetsmoney-to pay for expenditures, and from an accounting point of view, these outstanding government-issued pieces of paper constitute liabilities. ${ }^{1}$

Table 2 shows what happens if we consolidate the balance sheets of the private sector. The bonds are debts from private agents (in this example, the firms) to other private agents (in this example, the households), so they have canceled out. The only assets left in the balance sheets of the public sector are physical capital and the money issued by the government. Money can be thought of as a "claim" held by consumers and firms against the government. From the standpoint of the private sector, it is a net external, or outside, claim: it is outside money.

\footnotetext{
${ }^{1}$ If the money was backed by a real asset, e.g., gold, and also fully convertible, then the value of the gold would show up on the government's Assets column. In this case, the money issued is literally a liability representing the government's commitment to redeem the money for gold. In the case of fiat money, there need not be a counterpart on the Assets column of the government's balance sheet.
} 
Table 2

\begin{tabular}{c|cccccc}
\hline \hline \multicolumn{2}{c}{ Combined Private Sector } & & \multicolumn{2}{c}{ Government } \\
\hline \multicolumn{2}{c|}{ Assets } & Liabilities & & Assets & \multicolumn{2}{c}{ Liabilities } \\
\hline Money & 150 & & & & Money & 150 \\
Capital $\quad 200$ & & & & & \\
\hline & NW 350 & & & NW & -150 \\
\hline
\end{tabular}

Gurley and Shaw were interested in considering the effects of "open market operations" whereby the government issues money to purchase private bonds. Suppose, for example, that they purchase $\$ 15$ worth of private bonds. The resulting balance sheets are those in Table 3, which should be compared with those in Table 1 . The government now has $\$ 15$ worth of assets (the private bonds it purchased), and its liabilities have increased by $\$ 15$ because of the money issued to pay for these bonds. Households still hold $\$ 350$ worth of assets, but the composition of their portfolio has changed: they now hold $\$ 65$ in money and $\$ 10$ in bonds, as opposed to the $\$ 50$ in money and $\$ 25$ in bonds of Table 1 . The additional $\$ 15$ in money holdings comes from the new issue of money, backed by private bonds. These $\$ 15$ are government debt, but they are issued in payment for government purchases of private securities. They are a claim of consumers and firms against the world outside the private sector, but they are counterbalanced by private debt to the world outside, i.e., to the government. These additional cash balances are based on internal debt, so Gurley and Shaw referred to these $\$ 15$ as inside money.

Using the terminology of Gurley and Shaw, the $\$ 165$ stock of money in the economy of Table 3 consists of $\$ 150$ of outside money and $\$ 15$ of inside money. Both types of money are really the same physical object, e.g., green pieces of paper: The qualifiers inside and outside refer to the asset counterpart of the money. Inside money is backed by private domestic debt. Outside money is of a fiat nature (or backed by some other asset that is not in zero net supply within the private 
sector, e.g., gold). Note that if we consolidate the balance sheets of the private sector in Table 3, the net worth of the private sector is still $\$ 350$, just as in Table 2. Also, note that inside money is "endogenous" in that if, for example, firms pay off their whole debt, ceteris paribus, the money supply would shrink by $\$ 15$. Most likely, Gurley and Shaw were led to stress the distinction between inside and outside money because they viewed money and private debt as assets that played distinct roles in exchange, so that an economy with the balance sheets of Table 1, where households hold $\$ 50$ in cash and $\$ 25$ in private bonds, would function differently from an economy with the balance sheets of Table 3, where households hold $\$ 65$ in cash and $\$ 10$ in private bonds. $^{2}$

Table 3

\begin{tabular}{lr|rr}
\hline \hline \multicolumn{3}{c}{ Households } \\
\hline \multicolumn{2}{c|}{ Assets } & Liabilities \\
\hline Money & 65 & & \\
Bonds & 10 & & \\
Equity & 275 & & \\
\hline & & NW & 350 \\
\hline \hline
\end{tabular}

\begin{tabular}{lr|rr}
\hline \multicolumn{4}{c}{ Firms } \\
\hline \multicolumn{2}{c|}{ Assets } & \multicolumn{2}{c}{ Liabilities } \\
\hline Money & 100 & Bonds & 25 \\
Capital & 200 & Equity & 275 \\
& & & \\
\hline & & NW & 0 \\
\hline \hline
\end{tabular}

\begin{tabular}{|c|c|c|c|}
\hline \multicolumn{4}{|c|}{ Government } \\
\hline \multicolumn{2}{|c|}{ Assets } & \multicolumn{2}{|c|}{ Liabilities } \\
\hline \multirow[t]{2}{*}{ Bonds } & 15 & Money & 165 \\
\hline & & NW & -150 \\
\hline
\end{tabular}

The contemporary literature on monetary theory in general, and the subfield that deals with inside and outside money in particular, does not take as given that money and bonds play different roles. Instead, it seeks to understand whether they indeed do, and whether they ought to. The recent emphasis has been on trying to gain a deeper understanding of the precise roles that fiat money

\footnotetext{
${ }^{2}$ Refer to the section "Monetary Policy in a Modified Second Model," pp. 82-88. The theoretical analysis throughout the book is predominantly verbal, so it is not clear which are the precise trade-offs that agents consider when making a portfolio decision between money and bonds. The fact that households treat them as different assets is explicit in the Mathematical Appendix, where Alain C. Enthoven assumes distinct reduced-form demand functions for the two financial assets. Note that since bonds are nominal and risk less in this setup, it is not obvious why households would not treat them as perfect substitutes for money.
} 
and private debt play and ought to play, both as media of exchange and as vehicles to channel resources across economic agents, toward their most efficient use. ${ }^{3}$

\section{Contemporary Perspectives}

Gurley and Shaw simply asserted that agents would want to hold government-issued fiat money (this weakness was stressed by Patinkin, 1961), and for their purposes, the distinction between inside and outside money was relevant because they implicitly regarded them as imperfect substitutes. The modern literature on monetary theory seeks to identify the fundamental features of the basic economic environment that can make fiat money, or more generally, any asset that serves as a medium of exchange, valuable and socially beneficial. Modern theory also focuses on the differences and similarities between inside and outside money. When is outside money valued? Under which circumstances does inside money arise? Are inside and outside money substitutes or complements? Under which circumstances can they coexist? Are they both needed to achieve efficient outcomes?

Inside money is private debt that also circulates as a tangible medium of exchange. Thus, an economy with inside money must perform a delicate balancing act: On the one hand, it must have enough commitment or enforcement for credit to be feasible, but at the same time, credit must not function too well, for otherwise a tangible medium of exchange would be inessential. For example, Kocherlakota (1998) shows that a tangible medium of exchange is not essential if agents can commit to future actions or if their trading histories are public. Starting from this observation, Cavalcanti and Wallace (1999a) consider an environment where trading histories are

\footnotetext{
${ }^{3}$ This change of emphasis has led to a slightly different definition of inside money. The more modern use of the concept does not rely on the type of open market operations of Gurley and Shaw. Inside money need not be defined narrowly as circulating fiat money backed by private debt: The private debt itself is regarded as inside money if it circulates as means of payment among the private agents. (The more modern definition given at the beginning of this article encompasses both the case in which private debt circulates directly, as well as Gurley and Shaw's original example.) To illustrate, consider again the economy of Table 1. There is not enough information in that table to decide how much inside money there is in the economy: there are \$25 worth of inside assets, i.e., assets that are in zero net supply within the private sector, but whether these assets constitute inside money depends on whether they circulate as means of payment. If they do not—for example, if lenders merely hold the bonds until maturity to redeem them-then these bonds are not inside money.
} 
public for a subset of agents but private for the rest, and show that a social optimum requires note issue by those agents with public trading histories. In addition, those notes are in turn used in trade among the agents whose trading histories are private. Thus, in their environment, an optimum requires inside money.

Kiyotaki and Moore (2002) instead consider an environment where everyone is anonymous, and emphasize the importance of the agents' ability to make bilateral and multilateral commitments. The degree of (bilateral) commitment a borrower can make to an initial lender when selling a paper claim places a bound on the entire stock of private debt. The degree of (multilateral) commitment a borrower can make to repay any bearer determines the extent to which the borrower's debt can circulate in equilibrium. Kiyotaki and Moore find that only outside money circulates in economies with very low degrees of bilateral commitment. For higher but still low degrees of bilateral commitment, outside and inside money circulate alongside in equilibrium. For yet higher degrees, only inside money circulates, and when the agents' ability to make bilateral commitments is large enough, the economy can manage without any money, inside or outside. 


\section{Bibliography}

1. Cavalcanti, Ricardo de O., Andrés Erosa, and Ted Temzelides. "Private Money and Reserve Management in a Random-Matching Model.” Journal of Political Economy 107(5) (1999): 929-945.

2. Cavalcanti, Ricardo de O., and Neil Wallace. "A Model of Private Bank-Note Issue." Review of Economic Dynamics 2(1) (1999a): 104-136.

3. Cavalcanti, Ricardo de O., and Neil Wallace. "Inside and Outside Money as Alternative Media of Exchange." Journal of Money, Credit, and Banking 31(3) (August 1999b, Part 2): $443-457$.

4. Gurley, John G., and Edward S. Shaw. Money in a Theory of Finance. Brookings Institution, Washington, D.C., 1960.

5. Kiyotaki, Nobuhiro, and John Moore. "Evil Is the Root of All Money." Clarendon Lectures (Lecture 1), 2001.

6. Kiyotaki, Nobuhiro, and John Moore. "Inside Money and Liquidity." London School of Economics, mimeo, 2002.

7. Kiyotaki, Nobuhiro, and John Moore. "Financial Deepening." Journal of the European Economic Association 3(2-3) (April-May 2005): 701-713.

8. Kocherlakota, Narayana. "Money Is Memory." Journal of Economic Theory 81(2) (1998): $232-251$.

9. Patinkin, Don. "Financial Intermediaries and the Logical Structure of Monetary Theory: A Review Article." American Economic Review 51(1) (March 1961): 95-116.

10. Wallace, Neil. "Knowledge of Individual Histories and Optimal Payment Arrangements." Quarterly Review, Federal Reserve Bank of Minneapolis, Summer 2000. 